\title{
Accuracy of commercial kits and published primer pairs for the detection of periodontopathogens
}

\author{
Elisabeth Santigli ${ }^{1}$ - Eva Leitner ${ }^{2}$ - Gernot Wimmer ${ }^{3}$ - Harald H. Kessler ${ }^{4}$. \\ Gebhard Feierl $^{2}$ - Martin Grube ${ }^{5}$ - Katharina Eberhard ${ }^{6}$ - Barbara Klug ${ }^{1,5}$
}

Received: 18 December 2014 / Accepted: 10 February 2016 / Published online: 29 March 2016

(C) The Author(s) 2016. This article is published with open access at Springerlink.com

\begin{abstract}
Objectives Despite the input of microbiome research, a group of 20 bacteria continues to be the focus of periodontal diagnostics and therapy. The aim of this study was to compare three commercial kits and laboratory-developed primer pairs for effectiveness in detecting such periodontopathogens.

Materials and methods Fourteen bacterial mock communities, consisting of 16 randomly assembled bacterial strains, were used as reference standard for testing kits and primers. Extracted DNA from mock communities was analyzed by PCR in-house with specific primers and forwarded for analysis to the manufacturer's laboratory of each of the following kits: ParoCheckßKit 20, micro-IDent ${ }^{\circledR}$ plus11, and Carpegen ${ }^{\circledR}$ Perio Diagnostik.
\end{abstract}

Elisabeth Santigli

elisabeth.santigli@medunigraz.at

1 Division of Orthodontics and Maxillofacial Orthopedics, Department of Dentistry and Maxillofacial Surgery, Medical University of Graz, Billrothgasse 4, A-8010 Graz, Austria

2 Bacteriology and Mycology Laboratory, Institute of Hygiene, Microbiology and Environmental Medicine, Medical University of Graz, Universitätsplatz 4, 8010 Graz, Austria

3 Division of Prosthodontics, Restaurative Dentistry, Periodontology and Implantology, Department of Dentistry and Maxillofacial Orthopedics, Medical University of Graz, Billrothgasse 4, 8010 Graz, Austria

4 Research Unit Molecular Diagnostics, Institute of Hygiene, Microbiology and Environmental Medicine, Medical University of Graz, Universitätsplatz 4, 8010 Graz, Austria

5 Institute of Plant Sciences, University of Graz, Holteigasse 6, 8010 Graz, Austria

6 Center of Medical Research, Medical University of Graz, Stiftingtalstraße 24/1, 8010 Graz, Austria
Results The kits accurately detected Fusobacterium nucleatum, Prevotella intermedia/Prevotella nigrescens, Parvimonas micra, Aggregatibacter actinomycetemcomitans, Campylobacter rectus/showae, Streptococcus mitis, Streptococcus mutans, and Veillonella parvula. The in-house primers for F.nucleatum were highly specific to subtypes of the respective periopathogen. Other primers repeatedly detected oral pathogens not present in the mock communities, indicating reduced specificity.

Conclusions The commercial kits used in this study are reliable tools to support periodontal diagnostics. Whereas the detection profile of the kits is fixed at a general specificity level, the design of primers can be adjusted to differentiate between highly specific strains. In-house primers are more error-prone. Bacterial mock communities can be established as a reference standard for any similar testing.

Clinical relevance The tested kits render good results with selected bacterial species. Primers appear to be less useful for routine clinical diagnostics and of limited applicability in research. Basic information about the periodontopathogens identified in this study supports clinical decision-making.

Keywords Aggregatibacter actinomycetemcomitans . Campylobacter rectus/showae · Eikenella corrodens . Fusobacterium nucleatum $\cdot$ Microbiological diagnosis $\cdot$ Mock community $\cdot$ Molecular diagnostics · Oral biofilm · Parvimonas micra $\cdot$ Periodontal diagnostics $\cdot$ Prevotella intermedia $\cdot$ Prevotella nigrescens $\cdot$ Streptococcus mitis . Streptococcus mutans $\cdot$ Veillonella parvula

\section{Introduction}

Fighting periodontal diseases is one of the major goals of oral health care, as such diseases affect more than two thirds of the 
world population [1]. Periodontitis is a complex disease, with multiple causal factors simultaneously and interactively modulating the initiation, progression, and severity of its course [2]. Four main risk factors are recognized today, the foremost being dental and subgingival microbiota (referred to as "oral microbiota" or "oral biofilm"), in addition to individual genetic variability, lifestyle, and systemic factors [3-6]. Prime attention has previously been given to identifying the specific periodontopathic microorganisms, as both the onset and the characteristics of periodontal diseases are closely related to changes in the physiological oral habitat. When focusing on changes in this microbial community, different molecular methods can be used to detect oral pathogens related to periodontal disease [7-10]. Recently, laborious and timeconsuming culture assays have been replaced by quick and easy molecular methods. Techniques such as fluorescence in situ hybridization and confocal laser scanning microscopy, DNADNA hybridization, PCR, real-time PCR, and, more recently, next-generation sequencing have not only accelerated but also expanded the quest for unknown periodontopathogens [11-14]. Research results continue to broaden the picture of periodontal disease by applying novel methods to identify new bacterial species. The information gained from such studies is quite complex and standardized methods of data analyses are still being developed $[15,16]$.

A well-defined group of bacteria continues to be the focus of periodontal diagnostics and therapy. A specific bacterial composition of periodontopathic biofilm was first described in detail by Socransky and Haffajee. Five bacteria complexes are thus associated with periodontal disease to a varying extent, serving as targets or biomarkers for clinical research [17]. The red complex, which contains the bacteria that are most strongly related to periodontitis, has been studied extensively [18-21]. Yet, less has been reported about the relationship between periodontal disease and bacteria belonging to other complexes. In the last two decades, several commercial kits, based on various molecular technologies such as DNA-DNAhybridization and real-time PCR, have been developed for quick and accurate identification of such bacteria. Such kits are designed to support dentists in clinical decision-making. Not only do the kits indicate the presence of certain periodontopathogens but they also propose antimicrobial therapy options.

The use of mock communities as a reference standard has been previously shown to facilitate standardization, analysis and interpretation of microbiome data [22, 23]. Bacterial mock communities, consisting of a custom-selected variety of bacterial species, can also be employed to test the accuracy of primers and probes used in kits. For the present study, such microbial mock communities were randomly composed from a pool of 16 different bacterial species that represent key periodontal pathogens and other oral or human-associated bacteria. These mock communities were used to test the capability of accurately identifying bacteria, as shown by (1) three commercial kits: ParoCheck®Kit20 (Greiner Bio-One GmbH, Frickenhausen, Germany), micro-IDent®plus11 (Hain Lifescience $\mathrm{GmbH}$, Nehren, Germany), Carpegen ${ }^{\circledR}$ Perio Diagnostik (Carpegen GmbH, Münster, Germany) and (2) eleven previously published PCR primer pairs [7, 24-27].

\section{Methods}

\section{Mock communities used as reference standard in this study}

The bacterial strains for the mock communities were selected from reference strains based on the following criteria: (1) availability at the microbiological laboratory of the Institute of Hygiene, Microbiology and Environmental Medicine (IHMEM), Medical University of Graz; (2) suitability in terms of corresponding with the detection profile of the three commercial kits and the primers while roughly covering half of the species potentially identified by the kits (ParoCheck®Kit 20: 9 of 20; micro-IDent ${ }^{\circledR}$ plus11: 6 of 11 and Carpegen $\AA$ Perio Diagnostik: 3 of 6); (3) control strains reflecting commensals or contaminants of the oral cavity. Strains were included from the American Type Culture Collection (ATCC, Manassas, USA), Belgian Coordinated Collection of Microorganisms (LMG, University of Ghent, Belgium) and clinical isolates identified through 16S rRNA gene sequencing at the Institute of Hygiene, Microbiology and Environmental Medicine, Medical University of Graz. Within the selected pool of bacteria, more than half belonged to the microbial complexes described by Socransky [3]: Campylobacter rectus (LMG 7612), Fusobacterium nucleatum subsp. nucleatum (ATCC 25586), Prevotella intermedia, Peptostreptococcus micros (synonymous with Parvimonas micra) (ATCC 33270), Streptococcus mitis, Eikenella corrodens, Aggregatibacter actinomycetemcomitans serotype b (ATCC 43718), Capnocytophaga canimorsus, and Veillonella parvula. To test for specificity, additional control strains were added to the mock communities, including Aggregatibacter aphrophilus, Campylobacter coli (LMG 9220), Escherichia coli (ATCC 25922), Neisseria subflava, Prevotella denticola, Porphyromonas somerae, and Streptococcus mutans (all information on strains is listed in Table 1).

\section{Preparation of bacterial suspensions for mock community randomization}

Twelve bacterial mock community compositions were assessed by a random generator. Each strain was randomly added to four samples and excluded from four other ones. For the remaining four samples a 50/50 probability decided over addition of this strain. Additionally, one negative control 
Table 1 Laboratory strains used in the mock communities

\begin{tabular}{lll}
\hline Strain ID & Strain & Source \\
\hline A & Fusobacterium nucleatum & ATCC 25586 \\
& subsp nucleatum & \\
B & Prevotella intermedia/ nigrescens resp & MUGS \\
$\mathrm{C}$ & Campylobacter rectus & LMG 7612 \\
$\mathrm{D}$ & Aggregatibacter & ATCC 43718 \\
& actinomycetemcomitans & \\
& Serotype b & ATCC 33270 \\
$\mathrm{E}$ & Peptostreptococcus micros & \\
& (syn Parvimonas micra) & MUGS \\
$\mathrm{F}$ & Streptococcus mutans & MUGS \\
$\mathrm{G}$ & Veillonella parvula & MUGS \\
$\mathrm{H}$ & Neisseria subflava & MUGS \\
$\mathrm{I}$ & Eikenella corrodens & MUGS \\
$\mathrm{J}$ & Streptococcus mitis & MUGS \\
$\mathrm{K}$ & Aggregatibacter aphrophilus & MUGS \\
$\mathrm{L}$ & Prevotella denticola & MUGS \\
$\mathrm{M}$ & Capnocytophaga canimorsus & LMG 9220 \\
$\mathrm{N}$ & Campylobacter coli & MUGS \\
$\mathrm{O}$ & Porphyromonas somerae & ATCC 25922 \\
$\mathrm{P}$ & Escherichia coli & \\
& &
\end{tabular}

ATCC American Type Culture Collection (Manassas, USA), LMG Belgian Coordinated Collection of Microorganisms (University of Ghent, Belgium), MUGS Graz 16S rRNA Gene Sequencing Collection (Medical University of Graz, Austria)

(DNA-free water) and one positive control (all bacteria) were prepared, resulting in a total of 14 samples (P1 - P14 in Fig. 1). To mix bacteria in defined numbers according to bacterial culture, stock suspensions of each species were prepared in DNA-free water with turbidity equivalent to a McFarland standard of 0.5 (corresponding to $1.5 \times 10+\mathrm{E} 08 \mathrm{CFU} / \mathrm{ml}$ ). The stock solutions were then used to compose 12 defined mock communities by random selection, with each bacterial species subsequently assigned between six and nine times.
The final concentration of each bacterium in the mock was $7.5 \times 10+\mathrm{E} 06 \mathrm{CFU} / \mathrm{ml}$. Depending on the number of bacteria in the mock, concentrations varied between $3.0 \times 10+\mathrm{E} 07$ $\mathrm{CFU} / \mathrm{ml}$ and $1.2 \times 10+\mathrm{E} 08 \mathrm{CFU} / \mathrm{ml}$.

\section{DNA extraction}

Prior to DNA extraction, bacterial suspensions were pretreated by mixing $180 \mu \mathrm{l}$ of MagNA Pure Bacteria Lysis Buffer (Roche Applied Science, Penzberg, Germany), $20 \mu \mathrm{l}$ of proteinase $\mathrm{K}$ solution $(20 \mathrm{~g} / \mathrm{l})$, and $200 \mu \mathrm{l}$ of the bacterial suspension. The mixture was incubated at $65^{\circ} \mathrm{C}$ for $10 \mathrm{~min}$ and at $95^{\circ} \mathrm{C}$ for another $10 \mathrm{~min}$. After transferring $400 \mu \mathrm{l}$ of the suspension to the MagNA Pure Compact sample tube, the DNA was extracted through a fully automated procedure using the MagNA Pure Compact instrument (Roche) with the MagNA Pure Compact Nucleic Acid Isolation Kit I (Roche). The DNA bacterium purification protocol was chosen with an elution volume of $50 \mu \mathrm{l}$. The extraction was performed in duplicate, and eluates were pooled to a final volume of $100 \mu \mathrm{l}$. These comparable eluates were stored at $\mathrm{ms} 70^{\circ} \mathrm{C}$ pending analysis.

\section{Commercial kits}

Three commercial kits were applied to test the accuracy in identifying selected bacterial species assigned to the 14 mock communities as mentioned above. Referred to below also as "samples," the DNA extracted from the mock communities was forwarded for analysis to the manufacturer's laboratory of each of the following in vitro diagnostics (IVD) kits carrying the Conformité Européene (CE) label: ParoCheck®Kit 20 (Greiner Bio-One, Frickenhausen, Germany), microIDent@plus11 (Hain Lifescience GmbH, Nehren, Germany) and Carpegen ®Perio Diagnostik (Carpegen, Münster, Germany). ParoCheck®Kit 20, based on DNA chip technology, is used in the analysis of 20 periodontopathogens
Fig. 1 Study design and mock community composition by random selection. (Each bacterial strain present in six to nine samples)

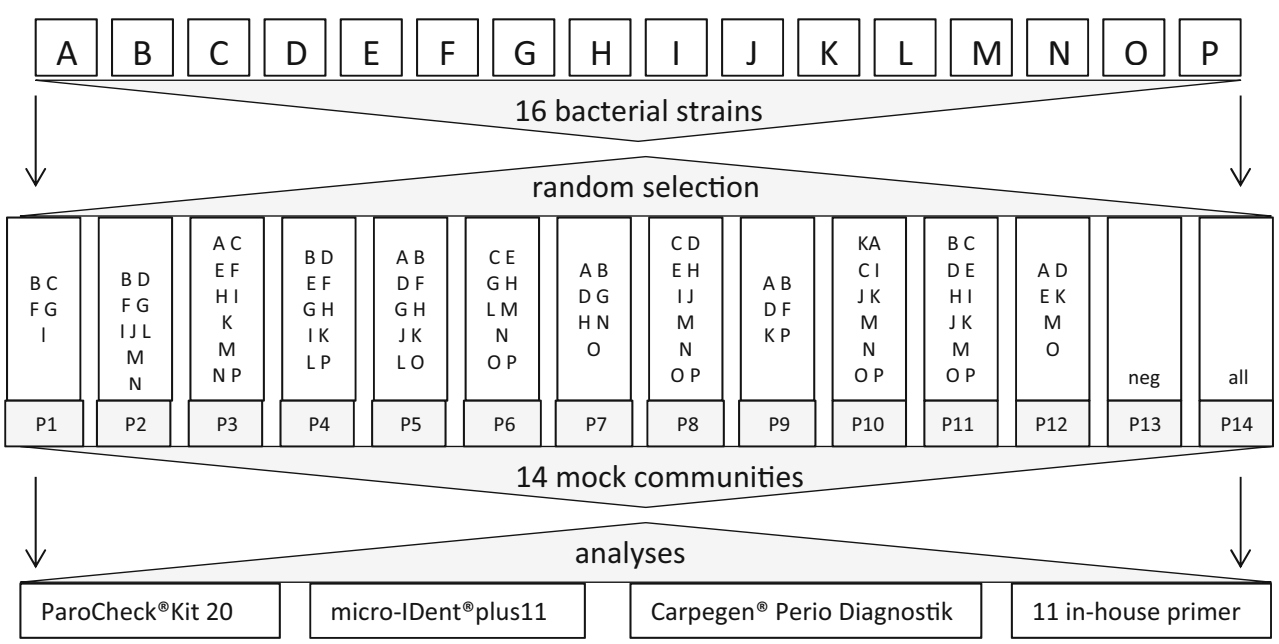


(detection limit of $10+$ E03 bacterial genomes). microIDent ${ }^{\circledR}$ plus 11, based on a DNA hybridization technology known as DNA-STRIP ${ }^{\circledR}$, supports the detection of 11 periodontopathogens (detection limit of $10+\mathrm{E} 03$ bacterial counts for Aggregatibacter actinomycetemcomitans and $10+\mathrm{E} 04$ for the other ten bacteria). Carpegen ${ }^{\circledR}$ Perio Diagnostik is a real-time PCR kit for identifying six periodontopathogens (detection limit of $2.5 \times 10+\mathrm{E} 02$ bacterial counts). A summary of the bacteria detected by the kits and their assignment to the microbial complexes described by Socransky [3] is given in Table 2.

\section{PCR primers}

Previously published primer pairs (referred to below as "primers") were applied in-house to identify the selected bacteria in the mock communities. For PCR, Illustra ${ }^{\mathrm{TM}}$ puReTaq Ready-To-Go PCR Beads (GE Healthcare) were used with $1-5 \mu l$ template DNA and $1-2 \mu l$ primer $(10$ $\mathrm{pmol} / \mu \mathrm{l})$ per $25 \mu \mathrm{l}$ as described in the manual. In cases where no signals resulted with the Illustra beads, PCR amplification was repeated with Phusion polymerase (Biozym) using $5 \mu \mathrm{l}$ template DNA and $1.5 \mu \mathrm{l}$ primer per $25 \mu \mathrm{l}$ PCR reaction. Singleplex PCR was performed in all cases according to protocols found in original publications (Table 3).

\section{Statistical analyses}

All statistical analyses were performed using SPSS version 21.0 (SPSS Inc., Chicago IL, USA). Clinical sensitivity and specificity were calculated on the basis of contingency tables. Cohen's Kappa coefficient, a statistical measure of inter-rater

Table 2 Bacteria in mock communities and detection profiles of test kits and published PCR primers

\begin{tabular}{|c|c|c|c|c|c|c|}
\hline & $\begin{array}{l}\text { ID in mock } \\
\text { community }\end{array}$ & Bacterium & $\begin{array}{c}\text { ParoCheck Kit } \\
20\end{array}$ & $\begin{array}{c}\text { micro-IDent } \\
\text { plus11 }\end{array}$ & $\begin{array}{l}\text { Carpegen Perio } \\
\text { Diagnostik }\end{array}$ & Primer \\
\hline $\begin{array}{l}\text { Detection } \\
\text { method }\end{array}$ & & & DNA-Chip & DNA-Strip ${ }^{\circledR}$ & Real-time PCR & PCR \\
\hline \multirow{21}{*}{ 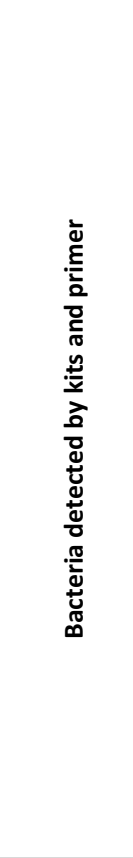 } & & Porphyromonas gingivalis & $\mathrm{x}$ & $\mathrm{x}$ & $\mathrm{x}$ & $\mathrm{x}$ \\
\hline & & Tannerella forsythia & $\mathrm{x}$ & $\mathrm{x}$ & $x$ & $\mathrm{x}$ \\
\hline & & Treponema denticola & $\mathrm{x}$ & $\mathrm{x}$ & $\mathrm{x}$ & $\mathrm{x}$ \\
\hline & & Campylobacter gracilis & $x$ & & & \\
\hline & A & Fusobacterium nucleatum & $x$ & $x^{*}$ & $x$ & $\mathbf{x}$ \\
\hline & B & Prevotella intermedia & $x$ & $x$ & $x$ & $x$ \\
\hline & & Prevotella nigrescens & $x$ & & & \\
\hline & & Streptococcus constellatus & $\mathrm{x}$ & & & \\
\hline & $\mathbf{E}$ & Parvimonas micra & $x$ & $x$ & & \\
\hline & D & Aggregatibacter actinomycetemcomitans & $x$ & $x$ & $x$ & $x$ \\
\hline & & Campylobacter concisus & $\mathrm{x}$ & & & \\
\hline & I & Eikenella corrodens & $\mathrm{x}$ & $\mathrm{x}$ & & $\mathrm{x}$ \\
\hline & & Capnocytophaga gingivalis & $\mathrm{x}$ & & & \\
\hline & & Capnocytophaga sp. & & $x$ & & \\
\hline & C & Campylobacter rectus/showae & $x$ & $x$ & & $x$ \\
\hline & & Eubacterium nodatum & $x$ & $x$ & & \\
\hline & $\mathbf{F}$ & Streptococcus mutans & $x^{* *}$ & & & $x$ \\
\hline & J & Streptococcus mitis & $\mathrm{x}$ & & & \\
\hline & & Actinomyces odontolyticus & $x$ & & & \\
\hline & G & Veillonella parvula & $x$ & & & \\
\hline & & Actinomyces viscosus & $\mathrm{x}$ & & & \\
\hline \multirow{8}{*}{ 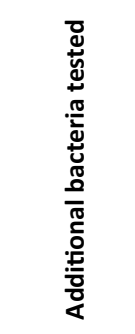 } & $\mathbf{H}$ & Neisseria subflava & & & & \\
\hline & $\mathbf{K}$ & Aggregatibacter aphrophilus & & & & \\
\hline & $\mathbf{L}$ & Prevotella denticola & & & & \\
\hline & $\mathbf{M}$ & Capnocytophaga canimorsus & & & & \\
\hline & $\mathbf{N}$ & Campylobacter coli & & & & \\
\hline & 0 & Porphyromonas somerae & & & & \\
\hline & $\mathbf{P}$ & Escherichia coli & & & & \\
\hline & & Lactobacillus fermentum & & & & $x$ \\
\hline
\end{tabular}

Colors assigned according to microbial complexes defined by Socransky et al. (1998)

${ }^{\text {a } I n c l u d i n g ~ F u s o b a c t e r i u m ~ p e r i o d o n t i c u m ~}$

${ }^{\mathrm{b}}$ Included in Streptococcus gordonii group 
Table 3 Primer details

\begin{tabular}{|c|c|c|c|c|}
\hline Primer name & Sequence $5^{\prime}-3^{\prime}$ & Bacterium & $\begin{array}{l}\text { Base position (amplicon } \\
\text { length in bp) }\end{array}$ & Reference \\
\hline $\begin{array}{l}\text { PoGifw } \\
\text { PoGirev }^{\mathrm{a}}\end{array}$ & $\begin{array}{l}\text { AGG CAG CTT GCC ATA CTG CG } \\
\text { ACT GTT AGC AAC TAC CGA TGT }\end{array}$ & Porphyromonas gingivalis & $729-1,132(404)$ & Slots et al. [24] \\
\hline $\begin{array}{l}\text { TaFofw } \\
\text { TaForev }^{\mathrm{a}}\end{array}$ & $\begin{array}{l}\text { GCG TAT GTA ACC TGC CCG CA } \\
\text { TGC TTC AGT GTC AGT TAT ACC T }\end{array}$ & Tannerella forsythia & $120-760(641)$ & Slots et al. [24] \\
\hline $\begin{array}{l}\text { TreDefw }^{\mathrm{a}} \\
\text { TreDerev }^{\mathrm{a}}\end{array}$ & $\begin{array}{l}\text { TAA TAC CGA ATG TGC TCA TTT ACA T } \\
\text { TCA AAG AAG CAT TCC CTC TTC TTC TTA }\end{array}$ & Treponema denticola & $193-508(316)$ & Slots et al. [24] \\
\hline $\begin{array}{l}\text { Fv35-F1 } \\
\text { Fv35-R1 }\end{array}$ & $\begin{array}{l}\text { ATA ATG TGG GTG AAA TAA } \\
\text { CCC AAG GAA AAT ACT AA }\end{array}$ & $\begin{array}{l}\text { Fusobacterium } \\
\quad \text { nucleatum subsp. vincentii }\end{array}$ & not available (208) & Shin et al. [27] \\
\hline $\begin{array}{l}\text { Fs17-F14 } \\
\text { Fs17-R14 }\end{array}$ & $\begin{array}{l}\text { GAT GAG GAT GAA AAG AAA CAA AGT A } \\
\text { CCA TTG AGA AGG GCT ATT GAC }\end{array}$ & $\begin{array}{l}\text { Fusobacterium } \\
\quad \text { nucleatum subsp. fusiforme }\end{array}$ & not available (393) & Shin et al. [27] \\
\hline $\begin{array}{l}\text { PrInfw }^{\mathrm{a}} \\
\text { PrInrev }^{\mathrm{a}}\end{array}$ & $\begin{array}{l}\text { TTT GTT GGG GAG TAA AGC GGG } \\
\text { TCA ACA TCT CTG TAT CCT GCG T }\end{array}$ & Prevotella intermedia & $458-1,032(404)$ & Ashimoto et al. [25] \\
\hline $\begin{array}{l}\text { AgAcfw }^{\mathrm{a}} \\
\text { AgAcrev }^{\mathrm{a}}\end{array}$ & $\begin{array}{l}\text { AAA CCC ATC TCT GAG TTC TTC TTC } \\
\text { ATG CCA ACT TGA CGT TAA AT }\end{array}$ & $\begin{array}{l}\text { Aggregatibacter } \\
\quad \text { actinomycetemcomitans }\end{array}$ & $478-1,034(557)$ & Ashimoto et al. [25] \\
\hline $\begin{array}{l}\text { EiCofw }^{\mathrm{a}} \\
\text { EiCorev }^{\mathrm{a}}\end{array}$ & $\begin{array}{l}\text { CGA TTA GCT GTT GGG CAA CTT } \\
\text { ACC CTC TGT ACC GAC CAT TGT AT }\end{array}$ & Eikenella corrodens & not available (410) & Furcht et al. [7] \\
\hline $\begin{array}{l}\text { CaRefw }^{\mathrm{a}} \\
\text { CaRerev }^{\mathrm{a}}\end{array}$ & $\begin{array}{l}\text { TTT CGG AGC GTA AAC TCC TTT TC } \\
\text { TTT CTG CAA GCA GAC ACT CTT }\end{array}$ & Campylobacter rectus & $415-1,012(598)$ & Slots et al. [24] \\
\hline $\begin{array}{l}\mathrm{Sm} 479 \mathrm{~F} \\
\mathrm{Sm} 479 \mathrm{R}\end{array}$ & $\begin{array}{l}\text { TCG CGA AAA AGA TAA ACA AAC A } \\
\text { GCC CCT TCA CAG TTG GTT AG }\end{array}$ & Streptococcus mutans & $599-1,077(478)$ & Chen et al. [26] \\
\hline $\begin{array}{l}\text { LF1 } \\
\text { LF2 }\end{array}$ & $\begin{array}{l}\text { AAT ACC GCA TTA CAA CTT TG } \\
\text { GGT TAA ATA CCG TCA ACG TA }\end{array}$ & Lactobacillus fermentum & $196-529(337)$ & $\begin{array}{l}\text { (Dickson et al., } \\
\text { 2005) }\end{array}$ \\
\hline
\end{tabular}

${ }^{a}$ Names assigned in this study

agreement, was used to calculate the concordance of positive and negative test results. Complete agreement corresponds to $\mathrm{K}=1$, while lack of agreement (i.e., purely random coincidences of rates) corresponds to $\kappa=0$. A $p$ value $<0.05$ was considered statistically significant.

\section{Results}

All commercial kits performed well in the detection of the following periodontopathogens: $F$. nucleatum, P. micra, A. actinomycetemcomitans serotype b, C. rectus/showae, S. mutans, S. mitis group, and V. parvula. $P$. intermedia was not, however, detected by any of the three commercial kits; hence, this laboratory strain was retested and identified as $P$. nigrescens. After redefinition, negative results for $P$. intermedia were accurately obtained with all three kits. Two false positives remained, when PCR primers were applied to identify $P$. intermedia and then $P$. nigrescens. E. corrodens as part of the mock communities was falsely identified positively three times out of seven by both the PCR primers and ParoCheck ${ }^{\circledR}$ Kit 20 . The primer pairs tested in this study showed the poorest performance of all test systems (Table 4).

\section{ParoCheck®Kit 20}

When the mock communities were used to test the ParoCheck ${ }^{\circledR}$ Kit 20 DNA chip, eight out of nine periodontopathogens were identified accurately: A. Actinomycetemcomitans serotype b was correctly identified in all cases. F. nucleatum, P. nigrescens, $P$. micra, all representatives of the orange complex and representatives of the yellow complex, such as C. rectus/showae, S. mutans as part of the Streptococcus gordonii group, and $S$. mitis were accurately identified, as was $V$. parvula, a representative of the purple complex. E. Corrodens from the green complex was present in seven mock communities but detected in ten, resulting in three false positives. Capnocytophaga species (gingivalis, ochracea, sputigena) tested once as borderline positive though not present in the mock communities (Table 4).

\section{micro-IDent ${ }^{\circledR p l u s 11}$}

micro-IDent $\AA$ plus 11 correctly identified five bacteria present in the mock communities. A. actinomycetemcomitans serotype b, two representatives of the orange complex, F. nucleatum and P. micra, one representative of the yellow 
Table 4 Detection of selected bacteria in 14 mock communities - three test kits and PCR primer on the test bench

\begin{tabular}{|c|c|c|c|c|c|c|c|c|c|c|c|}
\hline \multirow[t]{2}{*}{ ID } & \multirow{2}{*}{\multicolumn{2}{|c|}{$\begin{array}{l}\text { Bacteria included in } \\
\text { mock communities }\end{array}$}} & & \multicolumn{2}{|c|}{ ParoCheck $^{\circledR} 20$} & \multicolumn{2}{|c|}{$\begin{array}{c}\text { micro- } \\
\text { IDent }{ }^{\oplus} \text { plus11 } \\
\end{array}$} & \multicolumn{2}{|c|}{ Carpegen $^{\circledR}$ Perio } & \multicolumn{2}{|c|}{ PCR Primer } \\
\hline & & & & positive & negative & positive & negative & positive & negative & positive & negative \\
\hline \multirow{2}{*}{ A } & \multirow{2}{*}{\multicolumn{2}{|c|}{ Fusobacterium nucleatum }} & positive & 7 & 0 & 7 & 0 & 7 & 0 & 0 & (7) \\
\hline & & & negative & 0 & 7 & 0 & 7 & 0 & 7 & 0 & 7 \\
\hline \multirow{4}{*}{ B } & \multirow{4}{*}{$\begin{array}{l}\text { Prevotella } \\
\text { intermedia * }\end{array}$} & \multirow{2}{*}{$\begin{array}{l}\text { preliminary } \\
\text { evaluation }\end{array}$} & positive & 0 & (8) & 0 & (8) & 0 & (8) & 0 & (8) \\
\hline & & & negative & 0 & 6 & 0 & 6 & 0 & 6 & 2 & 4 \\
\hline & & \multirow{2}{*}{ re-evaluation } & positive & 0 & 0 & 0 & 0 & 0 & 0 & 0 & 0 \\
\hline & & & negative & 0 & 14 & 0 & 14 & 0 & 14 & 2 & 12 \\
\hline \multirow{2}{*}{$\mathbf{E}$} & \multirow{2}{*}{\multicolumn{2}{|c|}{ Parvimonas micra }} & positive & 7 & 0 & 7 & 0 & - & - & - & - \\
\hline & & & negative & 0 & 7 & 0 & 7 & - & - & - & - \\
\hline \multirow{2}{*}{ D } & \multirow{2}{*}{\multicolumn{2}{|c|}{$\begin{array}{l}\text { Aggregatibacter } \\
\text { actinomycetemcomitans }\end{array}$}} & positive & 9 & 0 & 9 & 0 & 9 & 0 & 9 & 0 \\
\hline & & & negative & 0 & 5 & 0 & 5 & 0 & 5 & 0 & 5 \\
\hline \multirow{2}{*}{ I } & \multirow{2}{*}{\multicolumn{2}{|c|}{ Eikenella corrodens }} & positive & 7 & 0 & 7 & 0 & - & - & 7 & 0 \\
\hline & & & negative & 3 & 4 & 0 & 7 & - & - & 3 & 4 \\
\hline \multirow{2}{*}{ C } & \multirow{2}{*}{\multicolumn{2}{|c|}{ Campylobacter rectus/showae }} & positive & 7 & 0 & 7 & 0 & - & - & 7 & 0 \\
\hline & & & negative & 0 & 7 & 0 & 7 & - & - & 0 & 7 \\
\hline \multirow{2}{*}{$\mathbf{F}$} & \multirow{2}{*}{\multicolumn{2}{|c|}{ Streptococcus mutans ** }} & positive & 7 & 0 & - & - & - & - & 7 & 0 \\
\hline & & & negative & 0 & 7 & - & - & - & - & 0 & 7 \\
\hline \multirow{2}{*}{ J } & \multirow{2}{*}{\multicolumn{2}{|c|}{ Streptococcus mitis group }} & positive & 6 & 0 & - & - & - & - & - & - \\
\hline & & & negative & 0 & 8 & - & - & - & - & - & - \\
\hline \multirow{2}{*}{ G } & \multirow{2}{*}{\multicolumn{2}{|c|}{ Veillonella parvula }} & positive & 7 & 0 & - & - & - & - & - & - \\
\hline & & & negative & 0 & 7 & - & - & - & - & - & - \\
\hline
\end{tabular}

\section{Bacteria dedected but not}

included in mock communities

\begin{tabular}{|c|c|c|c|c|c|c|c|c|c|c|c|}
\hline & \multirow{2}{*}{\multicolumn{2}{|c|}{ Porphyromonas gingivalis }} & positive & & - & - & - & - & - & 0 & 0 \\
\hline & & & negative & - & - & - & - & - & - & 6 & 8 \\
\hline & \multirow{2}{*}{\multicolumn{2}{|c|}{ Treponema denticola }} & positive & - & - & - & - & - & - & 0 & 0 \\
\hline & & & negative & - & - & - & - & - & - & 3 & 11 \\
\hline \multirow{4}{*}{ B } & \multirow{4}{*}{$\begin{array}{l}\text { Prevotella } \\
\text { nigrescens * }\end{array}$} & \multirow{2}{*}{$\begin{array}{l}\text { preliminary } \\
\text { evaluation }\end{array}$} & positive & 0 & 0 & - & - & - & - & - & - \\
\hline & & & negative & (8) & 6 & - & - & - & - & - & - \\
\hline & & \multirow{2}{*}{ re-evaluation } & positive & 8 & 0 & - & - & - & - & - & - \\
\hline & & & negative & 0 & 6 & - & - & - & - & - & - \\
\hline & \multirow{2}{*}{\multicolumn{2}{|c|}{$\begin{array}{l}\text { Capnocytophaga species (gingivalis, } \\
\text { ochracea, sputigena) }\end{array}$}} & positive & 0 & 0 & 0 & 0 & - & - & - & - \\
\hline & & & negative & 1 & 0 & 0 & 0 & - & - & - & - \\
\hline & \multirow{2}{*}{\multicolumn{2}{|c|}{ Lactobacillus fermentum }} & positive & - & - & - & - & - & - & 0 & 0 \\
\hline & & & negative & - & - & - & - & - & - & 10 & 4 \\
\hline
\end{tabular}

\footnotetext{
${ }^{a}$ Re-evaluation revealed Prevotella nigrescens instead of Prevotella intermedia in the mock community
}

${ }^{\mathrm{b}}$ Included in Streptococcus gordonii group

complex, C. rectus/showae, and one of the green complex, $E$. corrodens, were correctly detected. None of the other six bacteria covered by micro-IDent ${ }^{\circledR}$ plus 11 showed up as false positives (Table 4).

\section{Carpegen ${ }^{\circledR}$ Perio Diagnostik}

Carpegen ${ }^{\circledR}$ Perio Diagnostik covers six periodontopathogens, three of which were included in the mock communities. 
Correct positive and negative results were obtained for A. actinomycetemcomitans serotype $\mathrm{b}, F$. nucleatum and $P$. intermedia (both orange complex). None of the three other bacteria covered by Carpegen ${ }^{\circledR}$ Perio Diagnostik showed up as false positives (Table 4 ).

\section{PCR primers}

PCR primers correctly identified three of the six bacteria included in the mock communities: A. actinomycetemcomitans serotype b, C. rectus/showae, and S. mutans (both yellow complex). Within the orange complex, $P$. intermedia was wrongly detected twice, rendering false positives in both evaluations for this bacterium (see above). F. nucleatum present in the mock communities was not detected in any of the seven positive samples. The tested primer pairs were shown to bind specifically to the $F$. nucleatum subspecies vincentii and fusiforme described in the original publications. The strain used in the mock communities was, in contrast, subspecies nucleatum. E. corrodens (green complex) was detected three times though not present in the mock communities. Other bacteria not included in the 14 mock communities were detected incorrectly: P. gingivalis $(n=6), T$. denticola $(n=3)$, and L. fermentum $(n=10)$ (Table 4$)$. Under the PCR conditions described in the original publications, unspecific bands could be detected on agarose gel for T. forsythia. Only samples showing bands with the accurate length were considered positive.

\section{Statistical agreement}

When applied, testing resulted in exact Kappa agreement of statistical significance for all but one bacterium included in the commercial kits: $F$. nucleatum, $P$. nigrescens, $P$. micra, C. rectus/showae, Streptococcus mitis group and S. mutans as part of the Streptococcus gordonii group, A. actinomycetemcomitans serotype $\mathrm{b}$ and $V$. parvula, with a corresponding sensitivity of $100 \%$ and a specificity of $100 \%$. The exception was $E$. corrodens, for which moderate agreement $(\kappa=0.57, p=0.07)$ was reached with ParoCheck $®$ Kit 20 and PCR primers, resulting in a sensitivity of $100 \%$ and a specificity of $57 \%$. When analyzed using PCR primers, false positives were rendered for $P$. intermedia in both rounds of evaluation with a specificity of $86 \%$, while the purported false negatives for $F$. nucleatum revealed no sensitivity at all for this species (see discussion and Table 5).

\section{Discussion}

More than 700 species are reported to contribute to oral bacteria diversity [28]. When recent next-generation sequencing studies on oral microbiomes are considered, estimates of the number of species-level phylotypes range to as much as 10,000 when different sampling sites and pooled data from healthy and diseased individuals are taken into account $[6,13,29$, 30]. While the microbiome picture is expected to get even bigger as a result of refined methods, to date only 20 bacterial species have found their way into marketed periodiagnostics. Over the last two decades, methods based on PCR and cloning strategies have replaced time-consuming culturing procedures and produced commercial kits that are easy to use in dental practice. Even though the broadened view necessitated taxonomies to be modified in time, the species routinely tested in daily practice still correspond to the microbial complexes described by Socransky $[17,31]$. In the present study, three commercial kits and formerly published PCR primers were tested for their accuracy in detecting A. actinomycetemcomitans serotype $b$ and representatives of the orange, green, yellow, and purple complexes using mock communities as a reference standard. This approach overcomes some limitations to culture techniques traditionally used as gold standard. In our study the mock communities were used to verify test instruments available for outcome measurement in clinical and scientific settings. Scientific evidence, though contradictory, tends to support the use of systemic antibiotics and/or local antimicrobials as adjuncts to periodontal treatment [32-35]. Clear guidelines and distinct protocols are still lacking. Therapy decisions are based on interventional studies and in vitro experiments [36-39]. Commercially available kits and PCR primers are currently used in periodontal risk assessment, in monitoring therapeutic success and as an aid in choosing appropriate antibiotics [40-48]. Therefore, their accuracy and also the relevance of single representatives should be considered prior to use. In this way, the inherent bias of a test system selected to investigate a given issue can be minimized.

\section{Fusobacterium nucleatum}

Fusobacterium nucleatum, a gram-negative obligate anaerobic rod, plays a major role in periodontal biofilm formation as a bridge between early and late colonizers [49]. Fluorescence in situ hybridization (FISH) shows F. nucleatum in only 12-hold biofilms [50]. The species is divided into four subspecies: nucleatum, polymorphum, animalis, and fusiforme. A fifth subspecies, vincentii, was recently reclassified and now belongs to the subspecies fusiforme [51]. Our mock communities contained F. nucleatum subsp. nucleatum. While all three kits were accurate without exception, the strain was not detected using the PCR primers. These results underscore the primers' high specificity for the subspecies fusiforme, as indicated in the original publications [27]. Jervøe-Storm et al. [8] and Verner et al. [52] showed that, compared with the cultivation method, detection reliability using real-time PCR varies from pathogen to pathogen. In their studies, F. nucleatum could not be distinguished from close relatives in the culturing 
Table 5 Agreement, sensitivity, and specificity of test kits and PCR primers (mock community as reference standard)

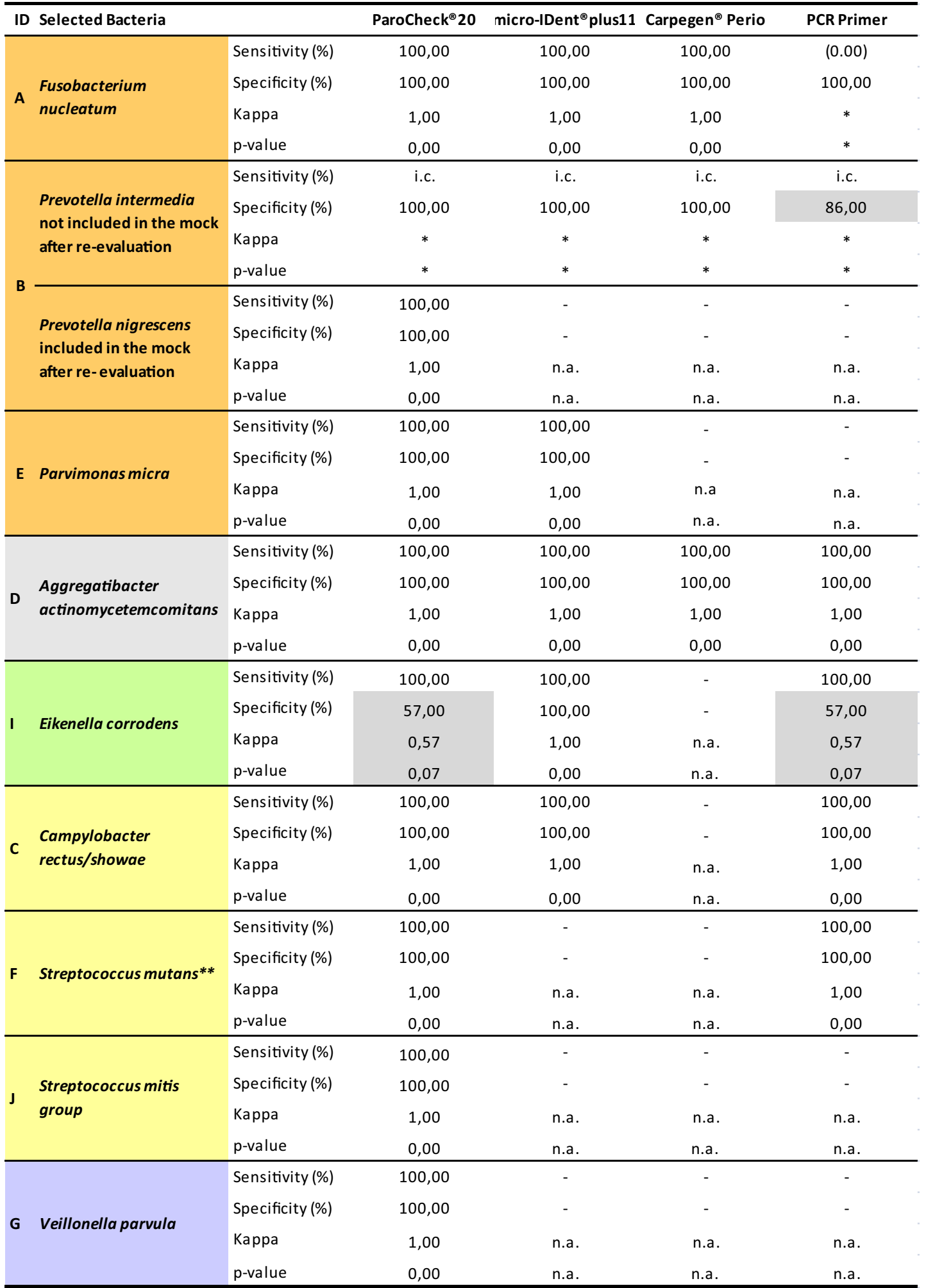

Interpretation of Kappa: $<0.0$ poor (no agreement), 0.0-0.2 slight agreement, $0.21-0.4$ fair agreement,

0.41-0.6 moderate agreement, $0.61-0.8$ substantial agreement, $0.81-1.0$ almost perfect agreement

n.a. not applicable (not included in the kit), i.c. incalculable (not included in reference standard)

*All samples rendered negative results

**Included in Strepotococcus gordonii group 
experiments, yielding poor agreement for this species. The use of well-defined mock communities and the fact that commercial kits do not differentiate among subspecies explain their consistent agreement in our study.

\section{Prevotella intermedia}

Prevotella intermedia (formerly Bacteroides intermedius) is a gram-negative obligate anaerobic rod that is often isolated from oral cavities. Closely related species, $P$. intermedia and $P$. nigrescens, can pose a challenge to differentiation, as reported by previous culture experiments [8, 25, 52]. Since only $P$. intermedia is associated with periodontal disease, reliable differentiation is vitally important [53].

\section{Parvimonas micra}

Parvimonas micra (previously Peptostreptococcus micros or Micromonas micros) occurs in pairs and short chains as grampositive obligate anaerobic cocci. As an orange complex periodontopathogen, it is associated with most types of oral infection such as periodontitis, endodontic and acute dentoalveolar infections, pericoronitis, and advanced dental caries [54, 55]. It also has been isolated from non-oral diseases, primarily from soft-tissue abscesses and bite wounds but also in the course of spondylodiscitis [56]. Recently, in a case control study, P. micra was found to be the only microbial predictor of periodontal parameters. $P$. micra is regarded as an important periodontal pathogen warranting more attention [57].

\section{Aggregatibacter actinomycetemcomitans}

Compared with other periodontopathogens, A. actinomycetemcomitans (previously Actinobacillus actinomycetemcomitans) is reported to be less prevalent and more heterogeneous. The genetic diversity and epidemiological distribution of A. Actinomycetemcomitansis strains has been frequently studied [58-62]. As a gram-negative facultative anaerobic subgingival biofilm former, some strains are clearly associated with periodontal disease [25, 63, 64]. While serotype $\mathrm{c}$ is commensal in healthy populations, serotype $\mathrm{a}$ and $\mathrm{b}$ strains are associated with severe periodontitis. $A$. actinomycetemcomitans strains exhibit a wide range of variability with regard to leukotoxin production. The specific JP2 clone, a highly leukotoxic strain, plays an important role in the development of aggressive periodontitis in certain populations [65-68]. Serotype $d$ and e are rare in all populations. However, there is still a lack of evidence about the infectious etiology of destructive periodontal disease [69]. In the present study, $A$. actinomycetemcomitans serotype $\mathrm{b}$ was included as reference strain in the mock community. It was detected accurately in all cases by the kits and PCR primers. Thus, when used as a reference standard, our mock communities result in a higher specificity for this species than has ever been previously published. The reported specificity levels range from 10 to $90 \%$ when real-time PCR was compared with bacterial cultures as the reference standard [70]. However, the kits and primer under investigation claim to cover serotype $\mathrm{a}, \mathrm{b}$, and $\mathrm{c}$ and are therefore unable to distinguish between the highly pathogenic genotype $b$ and the non-pathogenic genotype c. Future studies are needed to test more highly specific primers in screening for $A$. Actinomycetemcomitans strains of diverse pathogenicity.

\section{Eikenella corrodens}

Eikenella corrodens belongs to the Neisseriaceae family and is frequently found in the oral cavity. It is one of the HACEK bacteria (including: Haemophilus species, Aggregatibacter species, Cardiobacterium hominis, Eikenella corrodens, and Kingella species). This group of gram-negative facultative anaerobic bacteria frequently colonizes the oropharynx. E. corrodens has long been recognized as a cause of infective endocarditis [71]. Additionally, it has been implicated as an oral pathogen in Socransky's green complex. The accentuation of the green complex in periodontally diseased pockets needs to be considered in antibiotic therapy. The false positives obtained from ParoCheck ${ }^{\circledR K}$ Kit 20 and PCR primers when Neisseria subflava-also belonging to the Neisseriaceae family - was present in the mock communities, indicates a specificity problem.

\section{Capnocytophaga canimorsus}

Capnocytophaga spp., gram-negative facultative anaerobes, are present in habitats of the human oral cavity and some are associated with periodontitis. They belong to Sokransky's green complex. To test specificity, $C$. canimorsus was added to the mock communities. This strain is usually found in the microbiota of canines [72]. The one marginally positive result found with ParoCheck®Kit 20 may reflect an unspecific primer attachment due to the presence of $C$. canimorsus in the respective samples.

\section{Campylobacter rectus/showae}

Campylobacter showae strains in the human gingival crevices were first characterized and distinguished from $C$. rectus by Etoh et al. [73]. In general, $C$. showae strains are catalasepositive and resistant to nalidixic acid, while $C$. rectus strains are catalase-negative and sensitive to that antibiotic. Macuch and Tanner [74] suggested that $C$. showae may be associated with periodontal disease and confirmed the relationship between $C$. rectus and diseased subgingival sites. C. rectus can be used as a marker for periodontal disease progression [75]. Specificity testing against other more highly commensal strains of this group, such as $C$. gracilis and C. concisus, 
was not part of the present study, but such strains could be included in a future mock community.

\section{Streptococcus mitis group and Streptococcus mutans}

The Streptococcus mitis group (SMG) belongs to the viridans Streptococci. These ubiquitous initial colonizers constitute a majority of the cultivable bacteria found in dental plaque [76]. The Streptococcus mitis group comprises: S. mitis, $S$. sanguinis, $S$. parasanguinis, $S$. gordonii, S. oralis, $S$. cristatus, $S$. infantis, $S$. peroris, S. pneumoniae, and S. pseudopneumoniae. ParoCheck ${ }^{\circledR}$ Kit 20 was the only kit to include $S$. mitis. The kit promises detection of the entire $S$. mitis group as well as $S$. gordonii, which is referred to as the Streptococcus gordonii group and also comprises $S$. mutans. ParoCheck ${ }^{\circledR K i t} 20$ detected S. mutans in the Streptococcus gordonii group with $100 \%$ specificity. S. mutans primers developed by Chen et al. also showed comparable specificity [26]. micro-IDent@plus 11 and Carpegen ${ }^{\circledR}$ Perio Diagnostik exclude $S$. mutans from analysis, regarding it as being related to caries and not to periodontal desease. As Streptococcus spp. were shown to coaggregate in vivo with Veillonella spp., Fusobacterium nucleatum and Actinomyces naeslundi, they can be assumed to play a relevant role in periodontopathic biofilm [77]. Elevated $S$. mutans levels appear to correlate directly with increased severity of periodontal disease among untreated elderly patients [78]. The subgingival area is a microbial habitat not only for periopathogens but also for mutans streptococci, indicating a disturbed micro environment of the oral cavity [9]. They also may be of importance in the development of root caries in periodontitis patients [79]. However, the detection of $S$. mutans in subgingival plaque, while having no consequence for treating periodontal disease, might be useful in answering specific research questions. Future studies should provide insight not only into the diagnostic and therapeutic value of periodontal test kits and primers but also into their cost-effective application as preventive measures.

\section{Veillonella parvula}

Veillonella parvula, an anaerobic gram negative coccus and lactate utilizer, is almost always found in association with Streptococci. All are known as first colonizers on clean tooth surfaces in the human mouth. These highly prevalent representatives of the Firmicutes phylum are characteristic of the microbial community associated with common dental plaque and usually not associated with oral infections [31, 80]. Due to the great abundance of Firmicutes in oral biofilm, relative changes can be observed easily and might deliver valuable information for monitoring oral health and disease. In our study, $V$. parvula was only included in ParoCheck®Kit 20, which revealed accurate test results for all samples.

\section{Commercial kits versus laboratory-developed PCR primers}

Despite some limitations, commercial kits proved to be useful for obtaining information about the state, progression, and therapeutic outcome of periodontal disease [36, 81, 82]. Non-invasive subgingival paper-point insertion allows DNA to be collected at chairside within seconds. Paper points are packed in sterile tubes and sent to specialized laboratories. DNA extraction, preparation, and analysis are then performed within $3 \mathrm{~h}$. When compared with laboratory-developed primers, the major advantage of the commercial kits is their improved accuracy. In the case of A. actinomycetemcomitans, however, it would be helpful if detection was limited to the highly pathogenic genotype $b$, without detecting the nonpathogenic genotype c. In the routine diagnostic laboratory, it is preferable to use an IVD assay that bears the CE label and/or is approved or cleared by the FDA. It is also advisable to employ such kits in clinical research [40-48]. In this study, the protocol for bacterial suspension and DNA extraction was aimed to clearly exceed the detection limit of 10E3 given for the commercial kits. Further studies with a variation in study design are needed to test the performance levels of the kits at the detection limit. Carpegen ${ }^{\circledR}$ Perio Diagnostik in particular allows bacterial counts based on real-time PCR, thus enabling quantitative comparisons. The present study, however, was restricted to the specific detection of selected pathogenic bacteria and excluded quantification. The kit detects six representatives from the red, orange, and green complexes, all of them highly associated with periodontal disease. The other two kits tested in the present study, in contrast, allow only semi-quantitative analyses based on a DNA chip or DNA strip technology. On the other hand, the latter cover a wider range of bacterial species. microIDent ${ }^{\circ}$ plus 11 additionally includes representatives of the yellow complex, while ParoCheck®Kit 20 also covers species from the purple and blue complexes. While these additions do not necessarily improve diagnostic and therapeutic outcomes, they can provide additional value in clinical investigations of oral biofilm from healthy and deceased subjects.

Compared with the three tested commercial kits, the previously published PCR primers showed less agreement for the mock communities. In the case of $F$. nucleatum, the "inhouse" primers were obviously more specific to subtypes of the respective periopathogen, resulting in "pseudo"-negative results. Primers were selected with the intention of embedding them in microbiological screening to obtain scientific insights useful in the risk assessment of periodontal disease. The results in this study apply primarily to the strains included in the mock community. However, some bacteria not included in the mock communities, such as $P$. gingivalis, $T$. denticola, Capnocytophaga, and Lactobacillus fermentum, were nonetheless detected by primers. Due to the relevance for screening procedures, such results were reported as false positives, 
considering that no false negatives can be reported for a species or strain that is not part of the reference standard. These bacteria should not have been detected at all, regardless of the primers' specificity level. Primer pairs as tested in this study consequently present a twofold specificity problem: they either (a) seem to be very specific to subtypes/strains and are therefore limited to the purposes stated in the particular study or (b) their specificity is so low that bacteria not present are detected. These incorrect results highlight the difficulties in primer development. Applied molecular assays for primer composition and variable PCR conditions as extensively discussed elsewhere represent possible sources of error. We suggest validating primer pairs through prior testing using mock communities. Such should comprise a great variety of bacterial species, including species not present in the oral cavity but elsewhere in (and on) the body to assure high accuracy. Though more error-prone, the big advantage of "in house" primers is their taxonomic scope, which can be adjusted to be highly specific by designing them in line with various research or diagnostic purposes. Regardless of whether "homemade" or "instant," it is obvious that the more specific a primer is, the more accurately it will be able to resolve bacterial lineages.

\section{Mock communities}

The mock communities used in the present study were selected from the strains of bacteria that were available at the research laboratory. A limitation of this study is the fact that the bacteria selected did not include the full array of strains potentially covered by the tested kits or primers. However, A. actinomycetemcomitans serotype b and yet little investigated representatives of the orange, purple, green, and yellow complexes as described by Socransky et al. could be tested in this study, while bacteria from the red complex have been studied extensively elsewhere [18-21]. Strains were chosen from among those in the laboratory stock that corresponded as closely as possible to the detection profile claimed for the three commercial kits and the primers. In addition, bacteria not covered by the kits or primers were also included in order to test for general specificity. The goal in randomly mixing the bacteria among the mock communities was to ensure that the available strains were present in a variety of combinations and in varying proportions within the communities. Neither the dimension of pathogenicity of the selected strains was a criterion for inclusion nor was there a focus on increasing the number of detectable species. Rather, this study was intended as the first one of its kind, critically examining the accuracy of three commercially available test kits and published primers against mock communities as a potential formal reference standard. As the study shows, the approach can be easily standardized and adapted for more comprehensive criteria to be applied in future studies, such as equal distribution or a wider assortment of strains.

\section{Conclusion}

Presenting a first comparison of three commercial kits and laboratory-developed primer pairs with regard to effectiveness in detecting periodontopathogens, we confirm that the commercial kits used in this study are reliable tools for periodontal diagnostics and therapy. Whereas the detection profile of kits is fixed at a general specificity level, the design of primers can be adjusted to differentiate between highly specific strains. Inhouse primers are more error-prone and should be carefully designed and tested prior to use. We suggest bacterial mock communities be established as a reference standard for any similar testing of kits and primers.

Acknowledgments Open access funding provided by Medical University of Graz. The authors are grateful to Michael Bozic (Laboratory at the Research Unit Molecular Diagnostics, Medical University of Graz) for the excellent technical assistance in DNA isolation and Robert Schlarb (Native Translations, Austria) for language support. For processing the samples, the authors are indebted to: (a) Tobias Hain (Hain Liefescience GmbH, Nehren, Germany), microIDent®plus11 kits; (b) Tanja Koppler and Florian Winner (Lambda $\mathrm{GmbH}$ renamed to Greiner Bio-One Diagnostics GmbH, Rainbach, Austria), ParoCheck®Kits; and (c) Antje Rötger and Max Koltzscher (Carpegen Gmbh, Münster, Germany), Carpegen ${ }^{\circledR}$ Perio Diagnostik Kits. All three companies provided services at no cost.

Compliance with ethical standards This article does not contain any studies with human participants or animals performed by any of the authors.

Funding This study was supported by the Hygiene Fund of the Institute of Hygiene, Microbiology and Environmental Medicine at the Medical University of Graz, Austria.

Informed consent For this type of study, formal consent is not required.

Conflict of interest The authors declare that they have no conflict of interest.

Open Access This article is distributed under the terms of the Creative Commons Attribution 4.0 International License (http:// creativecommons.org/licenses/by/4.0/), which permits unrestricted use, distribution, and reproduction in any medium, provided you give appropriate credit to the original author(s) and the source, provide a link to the Creative Commons license, and indicate if changes were made.

\section{References}

1. Dye BA (2012) Global periodontal disease epidemiology. Periodontol 2000 2000(58):10-25

2. Laine ML, Crielaard W, Loos BG (2012) Genetic susceptibility to periodontitis. Periodontol 2000 58:37-68 
3. Socransky SS, Haffajee AD, Cugini MA, Smith C, Kent RL (1998) Microbial complexes in subgingival plaque. J Clin Periodontol 25: 134-144

4. Wimmer G, Köhldorfer G, Mischak I, Lorenzoni M, Kallus KW (2005) Coping with stress: its influence on periodontal therapy. J Periodontol 76:90-98

5. Jakubovics NS, Kolenbrander PE (2010) The road to ruin: the formation of disease-associated oral biofilms. Oral Dis 16:729-739

6. Abusleme L, Dupuy AK, Dutzan N, Silva N, Burleson JA, Strausbaugh LD, Gamonal J, Diaz PI (2013) The subgingival microbiome in health and periodontitis and its relationship with community biomass and inflammation. ISME J 7:1016-1025

7. Furcht C, Eschrich K, Merte K (1996) Detection of Eikenella corrodens and Actinobacillus actinomycetemcomitans by use of the polymerase chain reaction (PCR) in vitro and in subgingival plaque. J Clin Periodontol 23:891-897

8. Jervøe-Storm PM, Koltzscher M, Falk W, Dorfler A, Jepsen S (2005) Comparison of culture and real-time PCR for detection and quantification of five putative periodontopathogenic bacteria in subgingival plaque samples. J Clin Periodontol 32:778-783

9. Belda-Ferre P, Alcaraz LD, Cabrera-Rubio R, Romero H, SimónSoro A, Pignatelli M, Mira A (2012) The oral metagenome in health and disease. ISME J 6:46-56

10. Diaz PI (2012) Microbial diversity and interactions subgingival biofilm communities. Front Oral Biol 15:17-40

11. Loesche WJ, Lopatin DE, Stoll J, van Poperin N, Hujoel PP (1992) Comparison of various detection methods for periodontopathic bacteria: can culture be considered the primary reference standard? J Clin Microbiol 30:418-426

12. Suzuki N, Nakano Y, Yoshida A, Yamashita Y, Kiyoura Y (2004) Real-time TaqMan PCR for quantifying oral bacteria during biofilm formation. J Clin Microbiol 42:3827-3830

13. Zaura E, Keijser BJF, Huse SM, Crielaard W (2009) Defining the healthy core microbiome of oral microbial communities. BMC Microbiol 9:259

14. Klug B, Rodler C, Koller M, Wimmer G, Kessler HH, Grube M, Santigli E (2011) Oral biofilm analysis of palatal expanders by fluorescence in-situ hybridization and confocal laser scanning microscopy. J Vis Exp 56: doi:10.3791/2967

15. Pozhitkov AE, Beikler T, Flemmig T, Noble PA (2011) Highthroughput methods for analysis of the human oral microbiome. Periodontol 2000 55:70-86

16. Trajanoski S, Klug B, Klymiuk I, Bozic M, Grube M, Wimmer G, Santigli E (2013) Next-generation sequencing in microbiome analysis: factors affecting reproducibility of repeated biofilm sampling of the gingival sulcus of children. Journal of Dental, Oral and Craniofacial Epidemiology 1:34-44

17. Socransky SS, Haffajee AD (2002) Dental biofilms: difficult therapeutic targets. Periodontol 2000 28:12-55

18. Holt SC, Ebersole JL (2005) Porphyromonas gingivalis, Treponema denticola, and Tannerella forsythia: the red complex, a prototype polybacterial pathogenic consortium in periodontitis. Periodontol 2000 38:72-122

19. Hajishengallis G, Lamont RJ (2012) Beyond the red complex and into more complexity: the polymicrobial synergy and dysbiosis (PSD) model of periodontal disease etiology. Mol Oral Microbiol 27:409-419

20. Schillinger C, Petrich A, Lux R, Riep B, Kikhney J, Friedmann A, Wolinsky LE, Göbel UB, Daims H, Moter A (2012) Co-localized or randomly distributed? Pair cross correlation of in vivo grown subgingival biofilm bacteria quantified by digital image analysis. PLoS One 7, e37583

21. Thurnheer T, Belibasakis GN, Bostanci N (2014) Colonisation of gingival epithelia by subgingival biofilms in vitro: role of "red complex" bacteria. Arch Oral Biol 59:977-986
22. Caporaso JG, Lauber CL, Walters WA, Berg-Lyons D, Lozupone CA, Turnbaugh PJ, Fierer N, Knight R (2011) Global patterns of 16S rRNA diversity at a depth of millions of sequences per sample. Proc Natl Acad Sci U S A 108(Suppl):4516-4522

23. Diaz PI, Dupuy AK, Abusleme L, Reese B, Obergfell C, Choquette L, Dongari-Bagtzoglou A, Peterson DE, Terzi E, Strausbaugh LD (2012) Using high throughput sequencing to explore the biodiversity in oral bacterial communities. Mol Oral Microbiol 27:182-201

24. Slots J, Ashimoto A, Flynn MJ, Li G, Chen C (1995) Detection of putative periodontal pathogens in subgingival specimens bei 16S ribosomal DNA amplification with the polymerase chain reaction. Clin Infect Dis 20:304-307

25. Ashimoto A, Chen C, Bakker I, Slots J (1996) Polymerase chain reaction detection of 8 putative periodontal pathogens in subgingival plaque of gingivitis and advanced periodontitis lesions. Oral Microbiol Immunol 11:266-273

26. Chen Z, Saxena D, Caufield PW, Ge Y, Wang M, Li Y (2007) Development of species-specific primers for detection of Streptococcus mutans in mixed bacterial samples. FEMS Microbiol Lett 272:154-162

27. Shin HS, Kim MJ, Kim HS, Park SN, Kim DK, Baek DH, Kim C, Kook JK, Kim DK (2010) Development of strain-specific PCR primers for the identification of Fusobacterium nucleatum subsp. fusiforme ATCC 51190(T) and subsp. vincentii ATCC 49256(T). Anaerobe 16:43-46

28. Paster BJ, Olsen I, Aas JA, Dewhirst FE (2006) The breadth of bacterial diversity in the human periodontal pocket and other oral sites. Periodontol 2000 42:80-87

29. Keijser BJ, Zaura E, Huse SM, van der Vossen JM, Schuren FH, Montijn RC, ten Cate JM, Crielaard W (2008) Pyrosequencing analysis of the oral microflora of healthy adults. J Dent Res 87 : $1016-1020$

30. Griffen AL, Beall CJ, Campbell JH, Firestone ND, Kumar PS, Yang ZK, Podar M, Leys EJ (2012) Distinct and complex bacterial profiles in human periodontitis and health revealed by $16 \mathrm{~S}$ pyrosequencing. ISME J 6:1176-1185

31. Dewhirst FE, Chen T, Izard J, Paster BJ, Tanner ACR, Yu W, Lakshmanan A, Wade WG (2010) The human oral microbiome. J Bacteriol 192:5002-5017

32. Feres M, Figueiredo LC, Soares GM, Faveri M (2015) Systemic antibiotics in the treatment of periodontitis. Periodontol 2000 67: 131-186

33. Rabelo CC, Feres M, Goncalves C, Figueiredo LC, Faveri M, Tu YK, Chambrone L (2015) Systemic antibiotics in the treatment of aggressive periodontitis. A systematic review and a Bayesian network meta-analysis. J Clin Periodontol 42:647-657

34. Matesanz-Perez P, Garcia-Gargallo M, Figuero E, BasconesMartinez A, Sanz M, Herrera D (2013) A systematic review on the effects of local antimicrobials as adjuncts to subgingival debridement, compared with subgingival debridement alone, in the treatment of chronic periodontitis. J Clin Periodontol 40:227-241

35. Herrera D, Alonso B, Leon R, Roldan S, Sanz M (2008) Antimicrobial therapy in periodontitis: the use of systemic antimicrobials against the subgingival biofilm. J Clin Periodontol 35:45-66

36. Cionca N, Giannopoulou C, Ugolotti G, Mombelli A (2009) Amoxicillin and metronidazole as an adjunct to full-mouth scaling and root planing of chronic periodontitis. J Periodontol 80:364-371

37. Herrera D, Matesanz P, Bascones-Martinez A, Sanz M (2012) Local and systemic antimicrobial therapy in periodontics. J Evid Based Dent Pract 12:50-60

38. Astasov-Frauenhoffer M, Braissant $\mathrm{O}$, Hauser-Gerspach I, Weiger R, Walter C, Zitzmann NU, Waltimo T (2014) Microcalorimetric determination of the effects of amoxicillin, metronidazole, and their combination on in vitro biofilm. J Periodontol 85:349-357

39. Belibasakis GN, Thurnheer T (2014) Validation of antibiotic efficacy on in vitro subgingival biofilms. J Periodontol 85:343-348 
40. Carpegen GmbH (2014) Carpegen Perio ${ }^{\circledR}$ Diagnostik. In: . http:// www.carpegen.de/de/unsere-leistungen/carpegen-perio-diagnostik/ 2010-2011

41. Greiner Bio-One GmbH (2007) ParoCheck® Handbuch, Version BQ-016-00. In:http://www.greinerbioone.com/de/germany/ articles/catalogue/articles/351_1/ 2014

42. Hain Lifescience GmbH (2015) micro-IDent ${ }^{\circledR}$ und microIDent ${ }^{\circledR}$ plus11: Your test systemes for the reliable identifiction of 5 and 11 periodontopathogenic bacterial species. In: http://www. hain-lifescience.de/en/products/microbiology/dental-diagnostics/ micro-ident-und-micro-identplus.html 2010-2011

43. Mongardini C, Di Tanna GL, Pilloni A (2014) Lightactivated disinfection using a light-emitting diode lamp in the red spectrum: clinical and microbiological short-term findings on periodontitis patients in maintenance. A randomized controlled split-mouth clinical trial. Lasers Med Sci 29: $1-8$

44. Vianna ME, Horz HP, Gomes BP, Conrads G (2005) Microarrays complement culture methods for identification of bacteria in endodontic infections. Oral Microbiol Immunol 20:253-258

45. Jervoe-Storm PM, Alahdab H, Koltzscher M, Fimmers R, Jepsen S (2007) Comparison of curet and paper point sampling of subgingival bacteria as analyzed by real-time polymerase chain reaction. J Periodontol 78:909-917

46. Blome B, Braun A, Sobarzo V, Jepsen S (2008) Molecular identification and quantification of bacteria from endodontic infections using real-time polymerase chain reaction. Oral Microbiol Immunol 23:384-390

47. Eberhard J, Menzel N, Dommisch H, Winter J, Jepsen S, Mutters R (2008) The stage of native biofilm formation determines the gene expression of human beta-defensin-2, psoriasin, ribonuclease 7 and inflammatory mediators: a novel approach for stimulation of keratinocytes with in situ formed biofilms. Oral Microbiol Immunol 23:21-28

48. Apel S, Apel C, Morea C, Tortamano A, Dominguez GC, Conrads G (2009) Microflora associated with successful and failed orthodontic mini-implants. Clin Oral Implants Res 20:1186-1190

49. Kolenbrander PE, Andersen RN, Blehert DS, Egland PG, Foster JS RJP Jr, Colonizers L, Palmer RJ (2002) Communication among oral bacteria. Microbiol Mol Biol Rev 66:486-505, tabe of contents

50. Zijnge V, van Leeuwen MB, Degener JE, Abbas F, Thurnheer T, Gmur R, Harmsen HJ (2010) Oral biofilm architecture on natural teeth. PLoS One 5, e9321

51. Kook JK, Park SN, Lim YK, Choi MH, Cho E, Kong SW, Shin Y, Paek J, Chang YH (2013) Fusobacterium nucleatum subsp. Fusiforme Gharbia and Shah 1992 is a later synonym of Fusobacterium nucleatum subsp. vincentii Dzink et al. 1990. Curr Microbiol 66:414-417

52. Verner C, Lemaitre P, Daniel A, Giumelli B, Lakhssassi N, Sixou M (2006) Carpegen real-time polymerase chain reaction vs. anaerobic culture for periodontal pathogen identification. Oral Microbiol Immunol 21:341-346

53. Frandsen EV, Poulsen K, Kilian M (1995) Confirmation of the species Prevotella intermedia and Prevotella nigrescens. Int J Syst Bacteriol 45:429-435

54. van Dalen PJ, van Steenbergen TJ, Cowan MM, Busscher HJ, de Graaff J (1993) Description of two morphotypes of Peptostreptococcus micros. Int J Syst Bacteriol 43:787-793

55. Kumar PS, Griffen AL, Barton JA, Paster BJ, Moeschberger ML, Leys EJ (2003) New bacterial species associated with chronic periodontitis. J Dent Res 82:338-344

56. Uemura H, Hayakawa K, Shimada K, Tojo M, Nagamatsu M, Miyoshi-Akiyama T, Tamura S, Mesaki K, Yamamoto K, Yanagawa Y, Sugihara J, Kutsuna S, Takeshita N, Shoda N, Hagiwara A, Kirikae T, Ohmagari N (2014) Parvimonas micra as a causative organism of spondylodiscitis: a report of two cases and a literature review. Int J Infect Dis 23:5355

57. Al-hebshi NN, Al-Alimi A, Taiyeb-Ali T, Jaafar N (2015) Quantitative analysis of classical and new putative periodontal pathogens in subgingival biofilm: a case-control study. J Periodontal Res 50:320-329

58. Mombelli A, Gmür R, Lang NP, Corbert E, Frey J (1999) Actinobacillus actinomycetemcomitans in Chinese adults. Serotype distribution and analysis of the leukotoxin gene promoter locus. J Clin Periodontol 26:505-510

59. Kaplan JB, Schreiner HC, Furgang D, Fine DH (2002) Population structure and genetic diversity of Actinobacillus actinomycetemcomitans strains isolated from localized juvenile periodontitis patients. J Clin Microbiol 40:1181-1187

60. Cortelli JR, Cortelli SC, Jordan S, Haraszthy VI, Zambon JJ (2005) Prevalence of periodontal pathogens in Brazilians with aggressive or chronic periodontitis. J Clin Periodontol 32:860-866

61. Fine DH, Markowitz K, Furgang D, Fairlie K, Ferrandiz J, Nasri C, McKiernan M, Gunsolley J (2007) Aggregatibacter actinomycetemcomitans and its relationship to initiation of localized aggressive periodontitis: longitudinal cohort study of initially healthy adolescents. J Clin Microbiol 45:3859-3869

62. Jentsch H, Cachovan G, Guentsch A, Eickholz P, Pfister W, Eick S (2012) Characterization of Aggregatibacter actinomycetemcomitans strains in periodontitis patients in Germany. Clin Oral Investig 16: $1589-1597$

63. Ximénez-Fyvie LA, Haffajee AD, Socransky SS (2000) Microbial composition of supra- and subgingival plaque in subjects with adult periodontitis. J Clin Periodontol 27:722-732

64. Sanz M, Lau L, Herrera D, Morillo JM, Silva A (2004) Methods of detection of Actinobacillus actinomycetemcomitans, Porphyromonas gingivalis and Tannerella forsythensis in periodontal microbiology, with special emphasis on advanced molecular techniques: a review. J Clin Periodontol 31:1034-1047

65. Könönen E, Müller H (2014) Microbiology of aggressive periodontitis. Periodontol 2000 65:46-78

66. Haraszthy VI, Hariharan G, Tinoco EM, Cortelli JR, Lally ET, Davis E, Zambon JJ (2000) Evidence for the role of highly leukotoxic Actinobacillus actinomycetemcomitans in the pathogenesis of localized juvenile and other forms of early-onset periodontitis. J Periodontol 71:912-922

67. Haubek D, EnnibiOK, Poulsen K, Vaeth M, Poulsen S, Kilian M(2008) Risk of aggressive periodontitis in adolescent carriers of the JP2 clone of Aggregatibacter (Actinobacillus) actinomycetemcomitans in Morocco: a prospective longitudinal cohort study. Lancet 371:237-242

68. Haubek D, Johansson A (2014) Pathogenicity of the highly leukotoxic JP2 clone of Aggregatibacter actinomycetemcomitans and its geographic dissemination and role in aggressive periodontitis. J Oral Microbiol 6: doi:10.3402/jom.v6.23980. eCollection 2014

69. Hujoel P, Zina L, Cunha-Cruz J, Lopez R (2013) Specific infections as the etiology of destructive periodontal disease: a systematic review. Eur J Oral Sci 121:2-6

70. Atieh MA (2008) Accuracy of real-time polymerase chain reaction versus anaerobic culture in detection of Aggregatibacter actinomycetemcomitans and Porphyromonas gingivalis: a metaanalysis. J Periodontol 79:1620-1629

71. Chambers ST, Murdoch D, Morris A, Holland D, Pappas P, Almela M, Fernandez-Hidalgo N, Almirante B, Bouza E, Forno D, del Rio A, Hannan MM, Harkness J, Kanafani ZA, Lalani T, Lang S, Raymond N, Read K, Vinogradova T, Woods CW, Wray D, Corey GR, Chu VH, International Collaboration on Endocarditis Prospective Cohort Study Investigators (2013) HACEK infective endocarditis: characteristics and outcomes from a large, multinational cohort. PLoS One 8, e63181 
72. Gaastra W, Lipman LJA (2010) Capnocytophaga canimorsus. Vet Microbiol 140:339-346

73. Etoh Y, Dewhirst FE, Paster BJ, Yamamoto A, Goto N (1993) Campylobacter showae sp. nov., isolated from the human oral cavity. Int J Syst Bacteriol 43:631-639

74. Macuch PJ, Tanner AC (2000) Campylobacter species in health, gingivitis, and periodontitis. J Dent Res 79:785-792

75. Kinney JS, Morelli T, Braun T, Ramseier CA, Herr AE, Sugai JV, Shelburne CE, Rayburn LA, Singh AK, Giannobile WV (2011) Saliva/pathogen biomarker signatures and periodontal disease progression. J Dent Res 90:752-758

76. Loo CY, Corliss DA, Ganeshkumar N (2000) Streptococcus gordonii biofilm formation: identification of genes that code for biofilm phenotypes. J Bacteriol 182:1374-1382

77. Periasamy S, Kolenbrander PE (2009) Aggregatibacter actinomycetemcomitans builds mutualistic biofilm communities with Fusobacterium nucleatum and Veillonella species in saliva. Infect Immun 77:3542-3551
78. Contardo M, Díaz N, Lobos O, Padilla C, Giacaman R (2011) Oral colonization by Streptococcus mutans and its association with the severity of periodontal disease in adults. Revista clínica de periodoncia, implantología y rehabilitación oral 4:9-12

79. Van der Reijden WA, Dellemijn-Kippuw N, Stijne-van Nes AM, de Soet JJ, van Winkelhoff AJ (2001) Mutans streptococci in subgingival plaque of treated and untreated patients with periodontitis. J Clin Periodontol 28:686-691

80. Jenkinson HF (2011) Beyond the oral microbiome. Environ Microbiol 13:3077-3087

81. Eick S, Straube A, Guentsch A, Pfister W, Jentsch H (2011) Comparison of real-time polymerase chain reaction and DNAstrip technology in microbiological evaluation of periodontitis treatment. Diagn Microbiol Infect Dis 69:12-20

82. Guarnelli ME, Farina R, Cucchi A, Trombelli L (2010) Clinical and microbiological effects of mechanical instrumentation and local antimicrobials during periodontal supportive therapy in aggressive periodontitis patients: smoker versus non-smoker patients. J Clin Periodontol 37:998-1004 